NBER WORKING PAPER SERIES

THE POLITICAL ECONOMY OF WAR DEBTS AND INFLATION

Herschel I. Grossman

Working Paper No. 2743

NATIONAL BUREAU OF ECONOMIC RESEARCH

1050 Massachusetts Avenue

Cambridge, MA 02138

October 1988

Prepared for American Enterprise Institute Conference on Monetary Policy in an Era of Changes, November 1988. Peter Garber has given me many helpful suggestions. I have also benefitted from the comments of John Boschen, Phillip Cagan, and William Haraf. Suk Jae Noh has provided excellent research assistance. This paper is part of NBER's research program in Financial Markets and Monetary Economics. Any opinions expressed are those of the author not those of the National Bureau of Economic Research. 
NBER Working Paper \#2743

October 1988

THE POLITICAL ECONOMY OF WAR DEBTS AND INFLATION

ABSTRACT

This paper argues that before World War II the desire to maintain a trustworthy reputation for honoring war debts was an important factor in inducing deflationary postwar monetary policies in both the United Kingdom and the United States. The paper then asks why this policy objective did not serve to induce either a deflationary monetary policy or the honoring in full of war debts following world war II. The discussion focuses on differences in economic and political conditions atter World war II, especially the extension of the voting franchise, the increased economic and political power of organized labor, and, perhaps most importantly, the large postwar demands on national resources with which the servicing of World-War-II debts had to compete. The analysis also argues that, because these postwar developments were unforeseeable, but verifiable, contingencies, the partial default on World-War-II debts was excusable and, accordingly, did not cause either the United kingdom or the United states to lose its trustworthy reputation.

Hersche1 I. Grossman Department of Economics Brown University Providence, RI 02912 
Critical discussions of monetary policy, exemplified by the classic research of Friedman \& Schwartz (1963) as well as by the more recent analysis by Taylor (1981, 1982), commonly regard historical episodes of deflation and inflation to be policy mistakes, and attribute these mistakes to idiosyncratic perversity or stupidity of policymakers. These critics take the fact that policymakers typically do not articulate coherent explanations for their actions in terms of the maximizing calculus of economic rationality as evidence that policy is not based on correct economic analysis. A popular complementary line of argument associates episodes of detlation and intlation with shortcomings, not of particular policymakers, but of the institutional arrangements for policymaking. For example, Toma (1982, 1985) emphasizes perverse bureaucratic incentives, whereas Kydland \& Prescott (1977) and Barro \& Gordon (1983) focus on the inability of policymakers to commit themselves to resist the temptation to try to produce unanticipated inflation.

Whether the focus is on individual or on institutional shortcomings, this literature presumes that episodes of deflation or inflation are indications of bad monetary policy. This presumption has obvious plausibility because the negative consequences associated with deflationary or inflationary monetary policies are usually readily apparent. To counter the presumption in any particular case that deflation or inflation was bad policy, an economic historian must argue that the consequences of deflationary or inflationary policies, however undesirable, nevertheless were preterable to the consequences of hypothetical alternative policies. Such as argument usually would involve speculation about the objectives of policy or about the actual constraints on the achievement of these objectives. 
The analysis that follows accepts this challenge. It bases an account of postwar British and American episodes ot deflationary and inflationary monetary policies on the opposite presumption that qualitatively these historical events are convincingly explicable as rational policy choices -- that is, as choices that maximized the actual objectives of monetary policy subject to the policymaker's perceived constraints. The attraction of this research strategy is that it yields positive propositions about the dependence of monetary policy on the economic and political environment that can explicate past policy actions and can help to predict the future evolution of policy.

The analysis focuses specifically on the conflicting pressures on monetary policy resulting from the pervasive objective of maintaining a reputation for honoring war debts and from the other demands on national resources with which the servicing of war debts has had to compete. The presumption that postwar monetary policies have been qualitatively rational responses to these conflicting pressures does not preclude quantitative policy mistakes, but this presumption suggests that any regrets about past policy actions retlect the accumulation of information that was not available when policy was made and, given that policymakers process available intormation efficiently, that quantitative policy mistakes and regrets do not have a systematic pattern.

\section{Before World War II}

In British and American history, as in the history ot most countries, the incurring of public debt has been associated mainly with the financing of the temporarily high levels of public expenditures associated with major wars. After major wars, the ratio of public debt to annual GNP has declined, reversing most if not all of its wartime increase, with minor 
wars and recessions causing only brief interruptions in this process. 1 Figures 1 and 2, taken from Barro's Macroeconomics, summarize this history.

The United Kingdom and the United States, moreover, are notable in having regularly issued debts that are nominally denominated in the units of their own currencies. Such debts involve promises to pay a fixed number of units of an asset whose real value the sovereign debtor itself controls through its power either to specify the commodity equivalent of a unit of currency or to control the supply of fiat money. Presumably, a sovereign can issue nominally denominated debt only if lenders believe that the sovereign will not use its power to inflate in order to repudiate its debts. In practice, before World war II, both the UK and US always validated this belief, even to the extent of deflating in postwar periods following the issuance of large quantities of debt.

The behavior of the US and UK price levels associated with the French Wars, the American Civil War, and World War I dramatically illustrates this pattern. See Table 1 . In all four of these cases, the price level peaked during either the war itself or the period of postwar reconstruction, but then the price level declined and, despite subsequent periods of inflation and deflation, did not regain its peak until the next major war.

$l_{G i v e n}$ this pattern, the history of the public debt in the UK and the USA is broadly consistent with the tax-smoothing theory of fiscal deficits. See Barro (September 1987, pp. 237-242) for the UK evidence and additional references. The large fiscal deticits in the US during the 1980's have been associated with major investments in military hardware rather than with a major war. This episode still could turn out to be consistent with the taxsmoothing theory if subsequent experience shows that the 1980's did not witness an increase in the permanent level of federal government expenditures. 


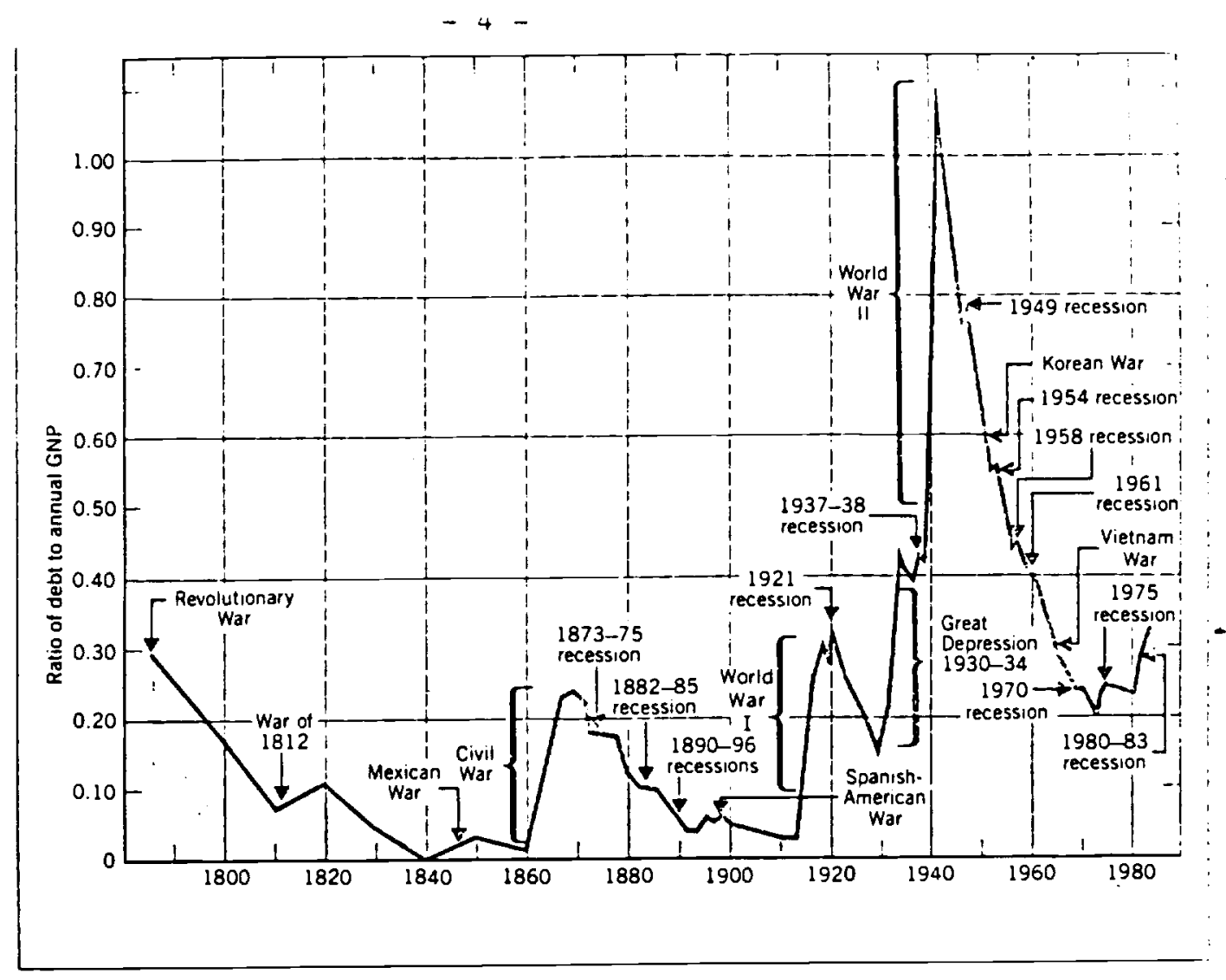

Figure 1 Behavior of the U.S. Public Debt, 1790-1985

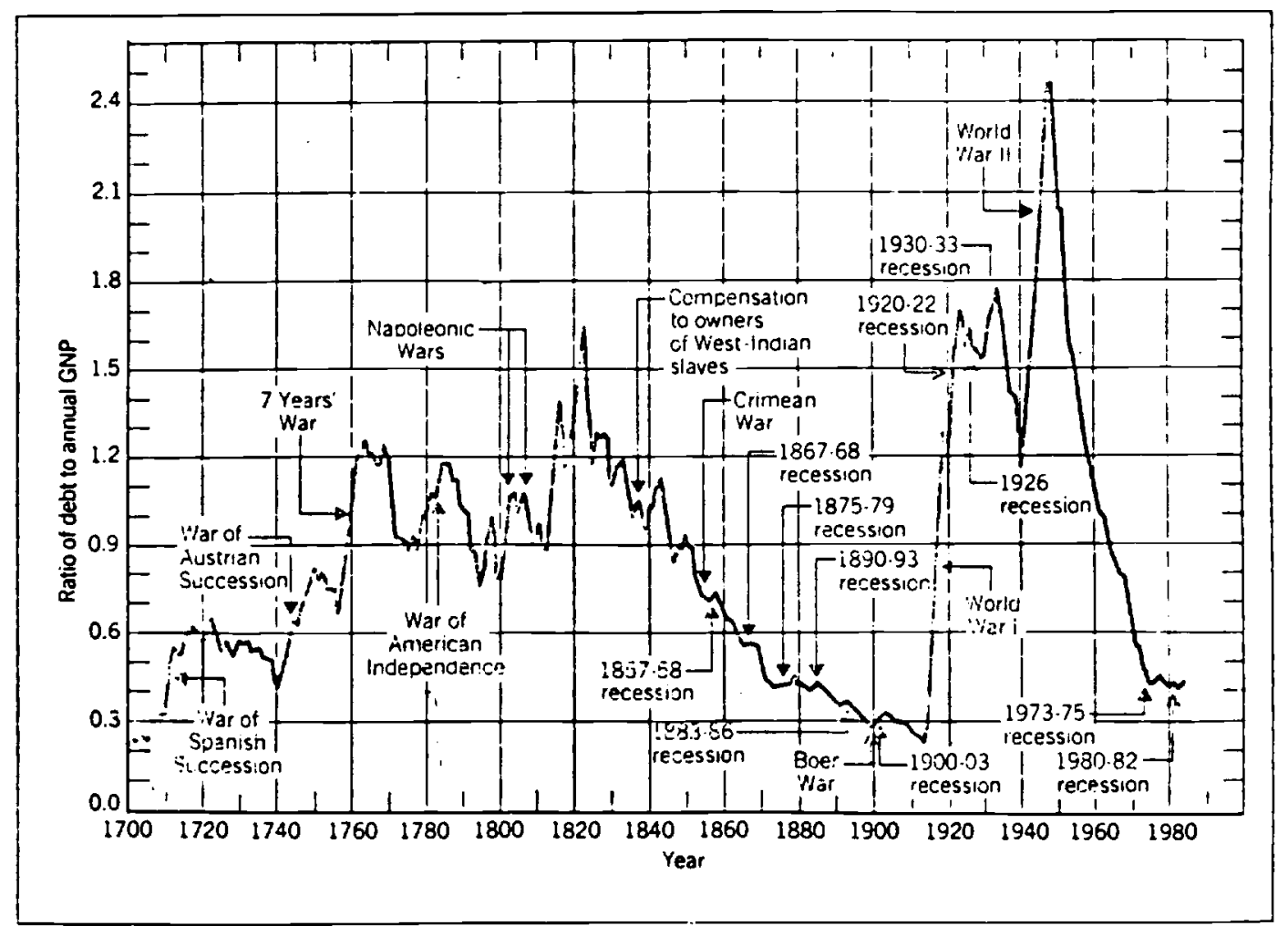

Figure 2 Jehavior of the Eritish Public Debt, 1700-1984

Source: Robert J. Barro, Macroeconomics Second Edition (New York:Wiley, 1987). 
Table 1

Major Wars and Prices

\begin{tabular}{|c|c|c|c|c|}
\hline & $\begin{array}{l}\text { War } \\
\text { Years }\end{array}$ & $\begin{array}{c}\text { Price Leve } 1 \\
\text { Peaked }\end{array}$ & $\begin{array}{l}\text { Subsequent } \\
\text { Troughs }\end{array}$ & $\begin{array}{c}\text { Peak } \\
\text { Kegained }\end{array}$ \\
\hline US Civil War & $1861-1865$ & 1866 & 1879,1896 & $1 y 16$ \\
\hline US WWI & $1917-1918$ & 1920 & 1933 & $1 y 44$ \\
\hline $\begin{array}{l}\text { UK French Wars } \\
\text { (including } \\
\text { Napoleanic Wars) }\end{array}$ & $1793-1815$ & 1812 & $\begin{array}{c}1820,1850 \\
1897\end{array}$ & $1 y 1 y=$ \\
\hline UK WWI & $1914-1918$ & 1920 & 1934 & 1947 \\
\hline
\end{tabular}

Data on price indexes from Mitchell \& Deane (1962), Friedman \& Schwartz (1982), and U.S. Commerce Department (1975).

As a consequence of this behavior of the price level, realized real rates of return on war debts before world war II were always highly positive. See the upper section of Table 2. Throughout the pre-World-War-II experience, the postwar decreases in the debt to GNP ratio were attributable to a combination of net debt redemptions and real economic growth.

How can we explain this pattern of deflationary postwar monetary policy and resulting positive real yields on war debts? Monetary policy and debt-servicing policy affect in a variety of ways the distribution of claims to national wealth and income. Actual policy, accordingly, must conform to the resolution of conflicting distributional interests that is achieved through the political process. The rentiers are clearly the most direct beneficiaries of deflation, and their spokespersons argue understandably that sound monetary policies have broader effects 
Table 2

Yields on War Debts

Years of Issue to Redemption of Representa-

War Years tive War Loan

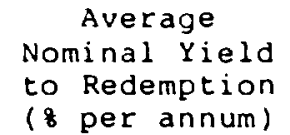

$1708-1808$

7.3

b. 3

UK War of Spanish

Succession

$1702-1713$

$1745-1845$

Succession

$1740-1748$

$1759-1859$

3.4

3.0

UK Seven Years War 1756-1763

$1775-1783$

$177 y-1879$

3.9

3.5

Independence

UK French Wars

(including

Napoleanic Wars)

UK World War I

1793-1815

$1804-1855$

1914-1918

$1916-1943$

$1861-1865$

$1863-1872$

$1917-1930$

US World War I

$1917-1918$

* * * *

US World War II

$1941-1945$

$1942-1963$

UK World War II

$1942-1965$

5.0

4.7

age

Real Yield to Redemption

( 8 per annum)

Table entries computed from data on debt issues and nominal yields in Homer (1963) and on price indexes in Mitchell deane (1962), Friedman \& Schwartz (1982), and U.S. Commerce Department (1975). (Because of the complex terms of much of this war debt and the complicated arrangements under which many of these loans were eventually called or converted, the entries in Table 2 are only approximations. Reasonable alternative calculations, however, would suggest that average realized real rates of return prior to World War II were even higher.) 
that benefit all income claimants. ${ }^{2}$ Another, less obvious but nevertheless important, aspect of distributional politics, which we shall emphasize further below, is the intensity of concern about the effects of deflationary monetary policy on aggregate employment and aggregate economic activity.

Without denying the importance of distributional considerations, given Britain's long history of recurring wars ot attrition against continental foes, it is easy to argue that a central consideration influencing British postwar monetary policy was the desire to maintain a trustworthy reputation for honoring war debts, without which efficient financing of the next war would not have been possible. Contemporary observers explicitly recognized that Britain's credit was so valuable that it was in the interest of British taxpayers to resist the temptation to repudiate war debts, to acquiesce in postwar deflationary policies, and to bear the resulting burden of servicing war debts. In his discussion of the Napoleanic Wars, the French historian Braudel writes:

The national debt was the major reason for the British victory. It had placed huge sums of money at England's disposal at the very moment when she required them. Isaac de Pinto was clear-sighted when he wrote in 1771: 'The scrupulous and inviolable exactness with which this interest (that on the national debt) has been paid, the idea of parliamentary guarantees, have established England's credit to the point where she has received loans that have surprised and astonished the rest of Europe.' He regarded the English victory in the seven Years' War (1756-1763) as the natural consequence. France's weakness, he claimed, lay in her poor credit arrangements. Thomas Mortimer was also right when in 1769 he admired in English public credit 'the permanent miracle of her policy, which has inspired both

In his comparative analysis of debt-servicing policy after world war I, Alesina (1988) focuses on the political power of competing income claimants. He attributes deflationary British monetary policy -- which he contrasts with more inflationary policies in Germany and France and a combination of inflation and forced conversion of debt in Italy -- to the political strength of Britain's rentiers, in alliance with businessmen who naturally opposed any threat to property rights. 
astonishment and fear in the states of turope'. Thirty years earlier, George Berkeley had celebrated it as 'the chief advantage which England has over france'--Braudel (1984), page 378 .

Similarly, as Keynes wrote in 1916:

If we can go on giving the army what they want longer than the Germans can do this to theirs, we may appear to win by military prowess. But we shall really have won by Einancial prowess -- quoted in Johnson (1971), page 187 .

Interestingly, in the extensive British debate about monetary policy after the First world War, the proponents of the return to gold at the prewar parity do not seem to have spoken explicitly about a possible need to finance another major war. The closest that Churchill came to making this argument apparently were words such as the following from a 1925 speech:

We have not adopted any of those cheap and easy methods by which to obtain a temporary glow of popularity by failing to make ... full provision for the repayment of our debts.... One can quite easily see the many temptations ... to try to tide over the ditticulties ot the moment by failing to do lourl duty to the responsibilities of the future -- quoted in James (1974), pages 3632-3633.

Perhaps this vague warning, in one of a series of speeches in which Churchill mainly stressed alleged commercial advantages of returning to gold, reflected Churchill's understandable reluctance to acknowledge explicitly the horrible possibility, which all thinking people must have feared, that the Great war had not settled the issues that caused it and that the Armistice and subsequent Treaty of Versailles were not viable, involving merely an American imposed truce made possible by the temporary exhaustion of the principal foes. 3 As one writer who was willing to express the unpleasant truth put it,

${ }^{3}$ Writing in 1920 , Colonel Repington prophetically entitled his memoirs, The First World War 1914-1918. According to Taylor (1965, page 2), "Repington devised lthis titlel at the time of the armistice to prevent the millenian folk from forgetting that the history of the world is the history of war!" 
The present series of wars, it seems likely, will continue for twenty or thirty years, and perhaps longer. That the first clash was inconclusive was shown brilliantly by the preposterous nature of the peace finally reached -- a peace so artificial and dishonest that the signing of it was almost equivalent to a new declaration of war -- Mencken (1922, page 199).

Taylor (1965, page 228) reports that from 1919 until 1932 british military planning was based on the optimistic presumption of "no" major war within the next ten years".

It is also worth noting that by 1931 the MacMillan Committee believed that the deflationary policy producing a positive return on war debts had gone too far. The Committee's Report spoke of "the immediate necessity to raise prices above their present level" and stated in support of this recommendation that

The increase in the burden of internal war debts ensuing on a rise in the value of gold money will present a most difficult problem if incomes generally become adjusted to the new lower level... A failure by the Central Banks of the world to attempt to redress the fall of prices, in our judgment, would endanger the principles on which modern economic society is founded, namely, the dependence of the productive process on the expectation of normal profit to individual concerns, and the sanctity of contract. For to allow prices to fall, whilst social forces maintain wage-costs, obliterates profit; and the attempt to reduce non-contractual incomes, without the power to abate contractual incomes immediately, jeopardises, both nationally and internationally, the sanctity of contract -- Macmillan Report, pages $115-116$.

Whatever the explicitly acknowledged motivations for Britain's return to gold after the First world war at the prewar parity, it is surely doubtful that Britain could have mobilized the resources that she needed to survive the Second World war it she had repudiated her World war I debts. Indeed, it seems only just that Churchill, as Britain's World war II leader, was able to benefit from his own prescient deflationary policies of twenty years before. Keynes himself, of course, opposed the post-WorldWar-I deflation for Keynesian reasons that foreshadow the postWorld-War-II experience, to which we shall soon turn. 
Turning to the United States after the Civil War, it is harder to argue that concern about financing the next major war was an important motivation for deflationary policies. The issue of preservation of the Union had been settled and tuture involvement in a major foreign war surely would not seem to have been a relevant possibility. Nevertheless, in his inaugural address of 1869, President Grant endorsed in the following terms the Public Credit Act that the Congress had already passed:

A great debt has been contracted in securing to us and our posterity the Union. The payment of this, principal and interest, as well as the return to a specie basis as soon as it can be accomplished without material detriment to the debtor class or to the country at large, must be provided for. To protect the national honor, every dollar of Government indebtedness should be paid in gold, unless otherwise expressly stipulated in the contract -quoted in Richardson (1903), page 7 .

We can interpret Grant's desire "to protect the national honor" as reflecting strategic reputational considerations, although this phrase also could have been a rhetorical cover for other (presumably distributional) objectives.

The British public debt traditionally consisted to a relatively large extent of long-term bonds, including bonds with no fixed maturity. Accordingly, British policy seems to have viewed the typical debt holder as an annuitant with the associated priority of maintaining the real value of the stream of interest payments. American public debt, in contrast, usually has been weighted towards shorter maturities. Moreover, during both World Wars, the Federal Reserve system policy of pegging interest rates encouraged the public to view government securities as liquid assets. (The Bank of England also put a floor under government bond prices during World War II.) The Federal Reserve even offered a preferential discount rate for advances to member banks on the collateral of government securities. Thus, when the Federal Reserve immediately after World War $I$ expressed its 
concern with protecting the value of government securities, this objective initially took the form of a desire to control credit expansion by methods that would not involve increased interest rates. But as inflation continued into 1920, the conflict intensified between maintaining the nominal market price of notes and bonds and maintaining the real value of their interest payments. Finally, the Federal Reserve allowed the temporary increase in interest rates and decline in security prices necessary to reverse the postwar inflation.

In the decade after World 'Nar I as a whole, as in the decade after the Civil war, American monetary policy had a distinctly deflationary bias, with the Federal keserve actively sterilizing gold inflows and guarding against "speculative excesses". This policy also kept inflationary expectations in check and nominal interest rates low, thereby protecting the real value of both the principal and interest payments on the war debt. Again, as in the Civil War case, the public record does not make clear the extent to which policy reflected strategic reputational considerations: Nevertheless, it seems clear that after World War I, Americans, whether internationalists or isolationists, clearly feared that World War I had been only the beginning of American involvement in international conflict. The internationalists' response was to try to reduce the possibility of further conflict, whereas the isolationists' response was to try to reduce the possibility of American involvement it. Neither strategy was certain of success, making the possible need to finance another major war a relevant policy consideration.

American monetary policy during the 1920's was not as deflationary as British monetary policy. But, between $192 y$ and 1933, the price level in the United States declined dramatically. Already by early 1932, the prevailing view, which was reflected in Congressional pressure for open-market purchases, was that the American deflation, like the earlier British deflation, had gone too far. These experiences, the more so 
because they were associated with economic stagnation in the United Kingdom and a depression in the United states, were among the factors that influenced monetary policy after World war II.

\section{After World War II}

Monetary policy since World War II in both the USA and the UK has been not deflationary but persistently inflationary. In both countries, the price level rose in every year of the tirst two postwar decades and by 1965 was almost twice its 1946 level in the USA and more than twice its 1946 level in the UK. As one consequence of this inflation, realized real rates of return on debts incurred to finance world war II were negative. See the lower section of Table 2. Since 1965 inflation has been even higher in both the US and UK. In 1987 the American price level was about $f i v e$ times its 1946 level and the British price level was about fifteen times its 1946 level. In contrast to the earlier postwar decreases in the debt to GNP ratio, the dramatic post-World-War-II decreases in this ratio shown in figures 1 and 2 are attributable mainly to inflation, with the effects of net increases in the nominal stock of debt and of real economic growth approximately offsetting each other.

The discussion that follows explores possible reasons tor this unusual peacetime inflation. Specifically, we ask the following question: Assuming that the desire to maintain a trustworthy reputation for honoring war debts was an important factor in inducing deflationary postwar monetary policies betore World War II, why did this policy objective not serve to induce either a deflationary monetary policy or the honoring in full of war debts following World war II?

Of course, the difference in post-World-War-II monetary policy, although quantitatively sharp, is one of degree not of kind. Most importantly, although realized real rates of return on World-War-II debts were slightly negative, and apparently less 
than what lenders expected, these debts were not repudiated. Moreover, although monetary policy was not deflationary after World War II, the objective of honoring war debts nevertheless seems to have been a somewhat constraining influence on intlation, at least until the mid-sixties by when the representative worldWar-II loan had been redeemed. 4

After World War II, as after World War I, the rederal Reserve's concern about the value of government securities initially caused it to focus on supporting bond prices. Stein (1984, page 82) reports that "President Truman remembered that when he came home from World War I the Liberty Bonds that he and other soldiers owned declined sharply in value. He did not want that to happen again." But, when serious inflationary fears developed on the outbreak of the Korean War, the Federal Reserve and the Treasury agreed in their famous accord that monetary policy should focus on controlling bank reserves. The rationale offered for this policy change is instructive and makes clear that a primary policy objective was to maintain the credit of the United States.

Early in February, 1951, there was a three-day meeting of the Open Market Committee devoted almost exclusively to what the Federal Reserve should do with increasing inflationary pressures and strong opposition to any modification of the support policy. The Committee approved a letter to the President explaining its position. The letter made four main points.

First, the System should do all in its power to preserve the purchasing power of the dollar because any policy which eats away the dollar's purchasing power would undermine confidence in the credit of the united

${ }^{4}$ The increase in inflation that began in the late sixties and continued through the seventies is beyond the focus of the present discussion. In the US pressure for monetary policy to create or to accommodate higher inflation during this period apparently resulted from the financing of the war in vietnam and from major disturbances in the world oil market. Unperceived increases in natural unemployment rates also seem to have played an important role in inducing inflationary policies in both the US and the UK. 
States and the public's willingness to buy and hold Government securities -- Anderson (1965, page 107 ).

What we are looking for then are reasons for why, although reputational considerations remained relevant, inflationary influences were relatively more important after World War II than they were after other wars, with the unprecedented consequence of negative realized real rates of return on World-War-II debts.

As noted above, conflict over the distribution of claims to national wealth and income is always an important factor in the determination of economic policy. Before World War II in the UK and USA, the political resolution of conflicting distributional interests apparently did not rule out postwar detlation. Those people whose wealth or income decreased as a result of detlation -- primarily debtors, including the taxpayers, who had to pay tor servicing the war debts, but also suppliers of labor services and profit recipients, to the extent that deflationary monetary policy depressed aggregate economic activity - either viewed the ettects of deflation as an acceptable cost to pay tor maintaining a trustworthy reputation for honoring war debts or were too politically weak relative to the rentiers to prevent detlationary policies. After World War II, some of the conditions that enabled the political process to produce a policy of honoring war debts in full clearly had changed.

By the end of World War II, two closely related political developments, the extension of the franchise and the emergence of organized labor as an effective economic and political force, apparently had transformed the bias of monetary policy from deflation to inflation. The political weakening of the rentiers associated with these developments meant that direct distributional consequences now weighed in the political process more heavily against deflation. Perhaps more importantly, whereas before World War II expressions of concern about the ettects of deflationary monetary policy on aggregate employment were put aside, the increased political strength of suppliers of labor 
services after World War II ruled out any policy that would increase the risk, already assumed to be large, of a return to the mass unemployment of the interwar period. Moreover, the admittedly excessive interwar deflation, and the resulting interwar prosperity of the rentiers in the midst of widespread economic hardship, made it hard to defend again the view that monetary policy should err on the side of preventing intlation. As noted above, Keynes' argument against the post-World-war-l deflation foreshadowed this change in priorities, but not until the end of World War II were political conditions conducive to codification of the Keynesian revolution in economic policy -that is, to the explicit adoption of high levels of aggregate employment and aggregate economic activity as policy goals, with the attendant inflationary bias of monetary policy. Another effect of these changed political conditions was the demise of political support for the gold standard as an obstacle to inflation.

Even with inflation developing after World War II as it did, it would have been possible to honor the World-War-II debts in full by compensating debt holders for the effects of inflation. Perhaps the most important obstacle to such a policy was the large postwar demands on national resources with which servicing of war debts had to compete. Both the United Kingdom and the United States faced unprecedented costs of postwar reconstruction. Great Britain had to rebuild its urban fabric, the housing, factories, and public buildings that wartime bombing had destroyed. The United States assumed the duty of assisting in the economic recovery of all of Western Europe. The Marshall Plan, moreover, was only one aspect of America's acceptance of responsibility tor defending the Free World. The cold war also involved the economic support of a network of military alliances and of large and modern armed forces and the willingness to use these forces, first in Korea and later in Viet Nam. 
In addition, during World war II the governments in both the United Kingdom and the United States had promised broad postwar rewards in exchange for maximum cooperation in the war ettort, and the increased economic and political power of organized labor nelped to enforce these promises.

Men talked of reconstruction as they had done during the first World war. This time they were determined not to be cheated, and therefore demanded the formulation of practical schemes while the war was on.

This demand was hard to resist. The governing classes were on their best behaviour, from conviction as well as from calculation -- Taylor (1965, page 567).

In 1943 the Churchill government, facing a wave of strikes, a revolt by Labour Members of Parliament, and by-election wins by the radical Commonwealth Party, adopted the Beveridge plan for universal social security. In his account of the Beveridge Report, Harris (1975, page 247) refers not only to "the desire to win and to keep the support of organized labor as a prerequisite of maintaining the war effort and ultimately of winning the war," but also to "the need to foster morale in the armed torces." Hicks (1954, page 202), in her discussion of british debt management in the immediate postwar years, emphasizes the budgetary strains resulting not only from "a large upsurge in social expenditure," but also from "a steadily mounting bill tor food subsidies." Besides competing directly for the resources that could be used to service war debts, the demands of reconstruction, the Cold War, and the welfare state also reinforced aversion to deflationary monetary policy, because it might depress aggregate economic activity and tax revenues.

Another relevant factor was the size of the World-War-II debt. For the United States, previous peaks in the ratio of public debt to annual GNP associated with the Civil War and World War I were about 0.25 and 0.3 . At the end of World War II, the ratio reached 1.1 . For the United Kingdom, previous peaks in the 
ratio associated with the Napoleanic Wars and World War I were about 1.75. At the end of World War II, the ratio reached 2.5 . These larger war debts meant that after World War II the costs of debt servicing had to be born more broadly, not as before mainly by taxes on propertied people, and, accordingly, that a policy of honoring war debts in full would have required political support from new taxpayers who did not have as strong a vested interest in secure property rights.

Another difference since 1945 that might seem to be relevant is military technology, especially the invention of nuclear weapons. By the early fifties, military planners had recognized that nuclear weapons had made obsolete the war of attrition, in which, as in the Napoleanic Wars, American Civil War, and world Wars I and II, the victor is the side that can mobilize the most resources for the longest period. Accordingly, in their influential book, Hitch \& Mckean (1960, page 15) stressed that "the superior economic war potential of the United States is important only to the extent that it has been effectively diverted to security purposes before war starts." But, as Hitch \& McKean also recognized, "preparation for and deterrence of thermonuclear war" now has the highest priority. It would be disastrous for our ability to deter attack to be even temporarily ineffective. Moreover, unexpectedly rapid technological developments could easily mean that maintaining an effective deterrent from time to time, as in the $1980^{\prime} \mathrm{s}$, would require temporary large military expenditures, which would be financed efficiently by borrowing. Thus, the invention of nuclear weapons probably has not reduced the value of being able to issue large amounts of debt and the associated value of a trustworthy reputation for honoring past debts. 


\section{Excusable Default}

Although realized real rates of return on world-war-II debts were negative, neither the United kingdom nor the United states seems to have lost its trustworthy reputation for honoring its debts. Both governments have been able to refinance old debts and to issue new debts, and the United States in particular has been able to increase its debt to GNP ratio during the ly8u's in order to finance a large investment in military hardware.

The evidence also strongly suggests that lenders did not anticipate the regative real rates of return on world-War-II debts. This evidence takes two forms: First, the concensus of contemporary commentators was that the main postwar problem would be deflation and depression.

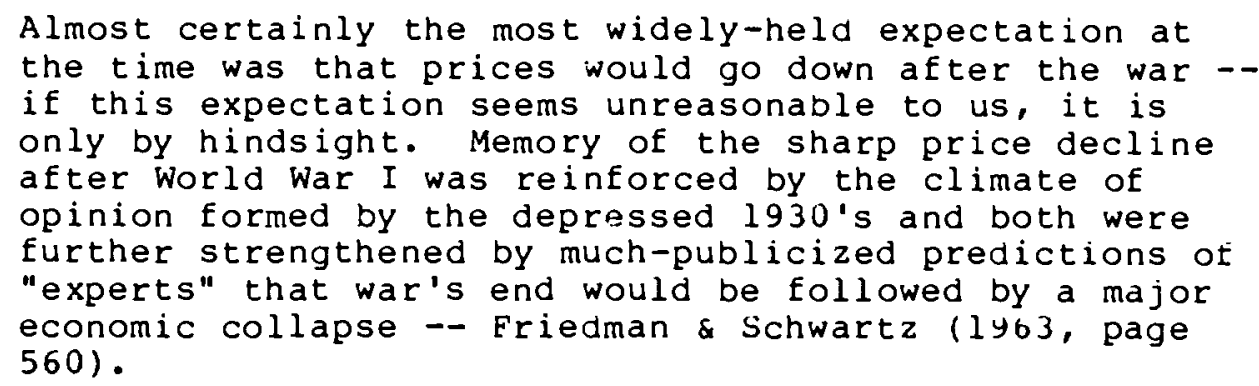

Second, although interest rates on bonds did not rise above 2.5 percent until the accord, calculations by Murphy (ly5u) imply that private nonbank lenders ot only financed more than one-halt of the consolidated deficit of the federal government for tiscal years 1941 through 1945, but that they also increased their holdings of public debt in the immediate postwar years, even though they were no longer either constrained by wartine shortages or subject to patriotic exhortations. Thus, it seems clear that the inflation in the United Kingdom and the United States after World War II resulted in a partial default on WorldWar-II debts. Realized real rates of return were not only negative, but also surely less than lenders expected. 
In the theoretical analysis of Grossman \& Van Huyck (September 1988, December 1988), sovereign defaults occur as bad outcomes of debt servicing obligations that are implicitly contingent on the realized state of the world. The interpretation of sovereign debts as contingent claims implies that sovereign debts serve at least in part to shift to lenders risks associated with verifiable events that affect the fortunes of the sovereign. This interpretation of sovereign debts also implies that lenders sharply differentiate excusable defaults, which are justifiably associated with implicitly understood contingencies, from debt repudiation, which would be unjustifiable and inexcusable. Being consistent with lenders' expectations about state-contingent debt servicing, excusable default does not preclude continued access to loans.

This theory explains why the partial defaults on world-warII debts did not result in a loss of reputation. Lenders apparently understood that the obligation to service these debts was contingent on postwar events. The competing claims on national resources that materialized after World War II -especially the costs of postwar reconstruction, the welfare state, and the Cold War -- were unforeseeable, but verifiable, contingencies that made partial default excusable.

\section{Summary}

This paper has analyzed the response of postwar monetary policies in the United Kingdom and the United States to the conflicting pressures resulting from the pervasive objective of maintaining a trustworthy reputation for honoring war debts and from the other demands on national resources with which the servicing of war debts has had to compete. The paper argued that before World War II reputational considerations were an important factor in inducing deflationary postwar monetary policies. The 
paper then asked why this policy objective did not induce either a deflationary monetary policy or the honoring in full ot war debts following World War II. The discussion focused on differences in economic and political conditions after world war II, especially the extension of the voting franchise, the increased economic and political power of organized labor, and, perhaps most importantly, the large postwar demands on national resources with which the servicing of World-war-II debts had to compete. Finally, the analysis argued that, because these postwar developments were unforeseeable, but verifiable, contingencies, the partial default on world-War-II debts was excusable and, accordingly, did not cause either the United Kingdom or the United States to lose its trustworthy reputation. 
REEERENCES

A. Alesina, "The End of Large Public Debts," in High Public Debt: The Italian Experience, F. Giavazzi and L. Spaventa, editors (New York: Cambridge University Press, 1988).

C.J. Anderson, A Half-Century of Federal Reserve Policymaking, 1914-1964 (Philadelphia: Federal Reserve Bank, 1965).

R.J. Barro, "Government Spending, Interest Rates, Prices, and Budget Deficits in the United Kingdom, 1701-1918," Journal of Monetary Economics 20, September 1987.

R.J. Barro, Macroeconomics, Second Edition (New York: Wiley, 1987).

R.J. Barro and D.B. Gordon, "A Positive Theory ot Monetary Policy in a Natural Rate Model," Journal of Political Economy, 91, August 1983 .

Fernand Braudel, The Perspective of the World, Volume III (Paris: Librairie Armand Colin, 197y; Englisn translation, New York: Harper \& Row, 1984).

Committee on Finance and Industry, Report (MacMillan Report) (London: HMSO, 1931).

M. Friedman and A.J. Schwartz, A Monetary History of the United States, 1867-1960 (Princeton: Princeton University Press, 19631 .

M. Friedman and A.J. Schwartz, Monetary Trends in the United States and the United Kingdom: Their Relation to Income, Prices and Interest Rates, 1867-1975 (Chicago: University of Chicago Press, 1982).

H.I. Grossman and J.B. Van Huyck, "Nominally Denominated Sovereign Debt, Risk Shifting, and Reputation," NBEk Working Paper No. 2259, revised September 1988.

H.I. Grossman and J.B. Van Huyck, "Sovereign Debt as a Contingent Claim: Excusable Default, Repudiation, and keputation," American Economic Review, 78, December 1988. 
J. Harris, "Social Planning in War-Time: Some Aspects of the Beveridge Report," in War and Economic Development, Essays in Memory of David Joslin, J.M. Winter, editor (New York: Cambridge University Press, 1975).

U.K. Hicks, British Public Finances: Their structure and Development, 1880-1952 (New York: Oxford University Press, 1954 ).

C.J. Hitch and R.N. Mckean, The Economics of Defense in the Nuclear Age (Cambridge: Harvard University Press, 1y6u).

S. Homer, A History of Interest Rate (New Brunswick, NJ: Kutgers University Press, 1963).

R.R. James, editor, Winston S. Churchill: His Complete Speeches, 1897-1963, Volume IV, 1922-1928 (New York: Chelsea House, $1974)$.

Elizabeth Johnson, editor, The Collected Writings of John Maynard Keynes, Volume XVI, Activities 1914-1919 (London:

Macmillan, 1971 ).

F.E. Kydland and E.C. Prescott, "Rules Rather Than Discretion:

The Inconsisitency of Optimal Plans," Journal of Political

Economy, 85, June 1977.

H.L. Mencken, In Defense of Women (New York: Knopf, 1922).

B.R. Mitchell and P. Deane, Abstract of British Historical Statistics (New York: Cambridge University Press, 1yo2).

H.C. Murphy, The National Debt in War and Transition (New York: McGraw-Hill, 1950).

C. aC. Repington, The First World War 1914-1yly (London: Constable, 1920).

J.D. Richardson, A Compilation of the Messages and Papers ot the Presidents 1789-1902, Volume VII (Washington: Bureau of National Literature and Art, 1903).

H. Stein, Presidential Economics: The Making of Economic Policy from Roosevelt to Reagan and Beyond (New York: Simon and Schuster, 1984 ). 
A.J.P. Taylor, English History 1914-1945 (New York: Uxtord University Press, 1965).

J.B. Taylor, "Stabilization, Accommodation and Monetary Kules," American Economic Review Papers and Proceedings, 71, May 1981.

J.B. Taylor, "Establishing Credibility: A Rational Expectations Viewpoint," American Economic Review Papers and Proceedings, 72, May 1982 .

M. Toma, "Inflationary Bias of the Federal Reserve System: A Bureaucratic Perspective," Journal of Monetary Economics, 10, September 1982 .

M. Toma, "A Duopoly Theory of Government Money Production: The 1930s and 1940s," Journal of Monetary Economics, 15, May 1985.

U.S. Commerce Department, Historical Statistics of the U.S., Colonial Times to 1970 (Washington: USGPU, 1975). 